\title{
Effect of late planting heat stress on membrane thermostability, proline content and heat susceptibility index of different wheat cultivars
}

\author{
M. A. Hasan ${ }^{*}$, J. U. Ahmed ${ }^{2}$, M. M. Bahadur ${ }^{1}$ M. M. Haque ${ }^{1}$ and S. Sikder ${ }^{1}$ \\ 1 Department of Crop Botany, Hajee Mohammad Danesh Science and Technology University, Dinajpur, Bangladesh \\ 2 Department of Crop Botany, Bangabandhu Sheikh Mujibur Rahman Agricultural University, Gazipur, Bangladesh
}

Revised: 06 December 2006 ; Accepted: 20 April 2007

\begin{abstract}
Four wheat cultivars e.g., Aghrani, Kanchan, CB-30 and Sonora were tested under normal and post anthesis heat stress condition by seeding them on November 30 and December 30 to evaluate the heat tolerance of wheat in relation to proline content. Time to exceed $50 \%$ membrane leakage was about four times longer in Aghrani, Kanchan and CB-30 (120-150 min.) and the cultivars were grouped as heat tolerant (HT) than in Sonora (30 min) which considered as heat sensitive (HS). Due to post anthesis heat stress condition the HS cultivar Sonora in comparison to heat tolerant (HT) genotype exhibited larger decrease in kernel proline (47.2\%) along with larger increase in flag leaf proline $(122 \%)$. The heat tolerant cultivars exhibited distinctly higher relative individual kernel dry weight, higher kernel number per spike, higher relative grain yield and low susceptibility index for grain yield under post anthesis heat stress condition compared to heat sensitive cultivar. Strong correlation existed between heat killing time in membrane thermostability test and relative change to normal in proline content (both in flag leaf and kernel) and between heat susceptibility index for grain yield and relative change to normal in proline content.
\end{abstract}

Key words: Heat killing time, heat susceptibility index, late planting heat stress, proline content, wheat

\section{INTRODUCTION}

Wheat (Triticum aestivum L.) is an important cereal crop ranking number one globally and number two in Bangladesh both in terms of production and acreage ${ }^{3}$. Presently the crop covers an area of about 0.85 million hectares and produces about 1.9 million tonnes in Bangladesh $^{2}$. However, the average yield of wheat is low (2.5 tonnes/ha) compared to that of many other wheat growing countries of the world as well as the genetic yield potential under Bangladesh conditions ${ }^{2}$.

Late planting of wheat is one of the major reasons for yield reduction, since about $60 \%$ of the wheat crop is cultivated at late sowing conditions after harvesting the transplanted aman rice $^{3}$. In Bangladesh, late planting of wheat exposes it to high temperature at reproductive stage causing reduction of the number of kernels per spike ${ }^{4-7}$ and the size ${ }^{8-9}$. The net effect of these is the reduced grain yield. However, this problem will be further aggravated due to global warming, because in Bangladesh the annual mean temperature of $25.75^{\circ} \mathrm{C}$ will rise by about $0.21^{\circ} \mathrm{C}$ and $0.39^{\circ} \mathrm{C}$ by 2050 and 2100 , respectively ${ }^{10}$.

In spite of low yield of wheat due to post anthesis heat stress, cultivation of wheat cannot be avoided totally. Thus, the irrigation dependent Boro rice cultivation may need to be replaced in future by partially irrigated or non irrigated wheat cultivation to reduce the use of underground water. Therefore, efforts ought to be made to minimize the late sown yield reduction by screening or developing high temperature tolerant wheat genotypes/ varieties.

Membrane thermostability (MT) test is a widely used and acceptable method to evaluate heat tolerance, and the heat susceptibility index is used to evaluate yield parameters. Under supra optimal temperature, free proline is known to accumulate in different crops ${ }^{12,14}$. Proline is therefore, considered to be an useful component for evaluating the tolerance of a crop to high temperature ${ }^{15}$. Proline accumulation capacity may vary in different wheat 
genotypes under late planting heat stress conditions. However, in wheat, the heat tolerance in relation to proline content has not yet been evaluated in Bangladesh and probably also in the other countries of the world. We therefore carried out the present investigation to test the tolerance of wheat genotypes to heat stress in relation to proline accumulation capacity.

\section{METHODS AND MATERIALS}

Four wheat cultivars (Aghrani, Kanchan, CB-30 and Sonora) were tested under normal and post anthesis heat stress conditions by seeding them on November 30 and December 30 at the research farm of Bangabandhu Sheikh Mujibur Rahman Agricultural University (BSMRAU), Gazipur, Bangladesh during November, 2001 to May, 2002 season on an upland soil. The experiment was conducted in a split plot design with four replicates. The two growing conditions- normal growing condition (sowing on November 30) and post anthesis heat stress condition (sowing on December 30) were placed in the main plots as main plot treatments whereas four wheat cultivars were placed randomly in the sub-plots as sub-plot treatments. Seeds of four wheat cultivars were sown in rows $20 \mathrm{~cm}$ apart, at the rate of $120 \mathrm{~kg} / \mathrm{ha}$ in a unit plot size of $3 \mathrm{~m} \times 2 \mathrm{~m}$. A fertilizer dose of 100-38-25-28 kg/ha N, P, K and S was applied in the form of Urea, Triple Supper Phosphate (TSP), Muriate of Potash (MP) and Gypsum, respectively. The experimental plots were irrigated when necessary to maintain the soil water at available water level $(-0.33$ to -15 bars) using tensiometers dipping at $15 \mathrm{~cm}$ depth. Other intercultural operations were done accordingly.

Membrane Thermostability (MT) test: Membrane thermostability was measured as described in previous studies ${ }^{6}$. Flag leaf samples were collected at anthesis from five randomly selected plants of each genotype and replication. Two leaf discs $(10 \mathrm{~mm}$ in diameter) were collected from a flag leaf using a leaf puncher (CAT 162 model, Ronnd Open Industry Co. Ltd., Japan). The leaf discs were washed three times with deionized water to remove electrolytes adhering to leaf tissue, as well as electrolytes released from cut cells on the periphery of leaf discs. The test tubes ( $25 \mathrm{~mm} \times 150 \mathrm{~mm}$ ) were also rinsed with deionized water. Then ten leaf discs from five flag leaves were placed in a test tube and a piece of cotton was put on the leaf discs inside the test tube to prevent any injury of the discs by the electrode bar during conductance measurement. Thereafter $20 \mathrm{~mL}$ of deionized water was added to each tube.

The initial conductivity reading (I) of the test tube with leaf disc was taken with an electrical conductivity (EC) meter (Model SC 82, YOKOGAWA Electric
Corporation, Japan). The test tubes werc covered by aluminium foil and placed in a thermostatically controlled water bath incubator (Model BT-23, HITEC, Japan) maintaining a constant temperature of $55^{\circ} \mathrm{C}$. Electrical conductivity reading $(\mathrm{E})$ was also taken at $30 \mathrm{~min}$ intervals up to $4.5 \mathrm{~h}$. Subsequently, the samples were autoclaved at $121^{\circ} \mathrm{C}$ for 15 min to kill the leaf tissues completely. After autoclaving, the samples were again placed in a water bath to adjust them at the elevated temperature of $55^{\circ} \mathrm{C}$ and final conductance $(F)$ was measured. The percentage of injury induced by the elevated temperature during the time course ( $30 \mathrm{~min}$ ) was calculated as follows.

$$
\operatorname{Injury}(\%)=\frac{\text { E-I }}{\text { F-I }} \times 100
$$

Where,

$$
\begin{aligned}
& I=\text { The initial conductance } \\
& E=\text { The elevated temperature conductance } \\
& F=\text { The final conductance after autoclaving }
\end{aligned}
$$

The time required to cause $50 \%$ injury at $55^{\circ} \mathrm{C}$ was defined as the heat killing time. Longer heat killing time in MT test indicated heat tolerance and shorter heat killing time indicated heat sensitivity of wheat cultivars.

Estimation of proline: Proline content of flag leaf and kernel at $8 \mathrm{~d}$ after anthesis in all wheat genotypes grown under two different growing conditions were estimated. At $8 \mathrm{~d}$ after anthesis, flag leaves and ears from each replication of each cultivar were collected and immediately kept in an ice-bag and brought to Crop Botany Laboratory of BSMRAU for proline estimation. The kernels from the ear were separated and one-gram fresh weight of both flag leaf and kernels were taken for proline estimation. Subsequently proline was estimated by the method described in previous studies ${ }^{16}$.

At first ninhydrin reagent was prepared and utilized for proline estimation within $2 \mathrm{~h}$ of preparation keeping it in a refrigerator in a brown bottle. For preparing the ninhydrin reagent, addition of $30 \mathrm{~mL}$ glacial acetic acid and $30 \mathrm{~mL} 6 \mathrm{M}$ orthophosphoric acid was mixed with $1.25 \mathrm{~g}$ of ninhydrin. It was subsequently heated and stirred gently to dissolve but the temperature was not allowed to exceed $70^{\circ} \mathrm{C}$. Proline standards were prepared for 0,2 , $4,6,8,10,12,14,16,18$, and $20 \mathrm{mg} /$ litre with distilled water.

The fresh samples were crushed in mortar and pestle and the material was homogenized in $10 \mathrm{~mL} 3 \%$ sulphosalicylic acid until no large segments of plant material remained. Homogenate was filtered through Whatman No. 2 filter paper and washed with $3 \%$ sulphosalicylic acid and the volume was set to $25 \mathrm{~mL}$. 
Two $\mathrm{mL}$ of the filtrate and each standard proline solution were then reacted with $2 \mathrm{~mL}$ of ninhydrin reagent and $2 \mathrm{~mL}$ of glacial acetic acid in a pyrex test tube, boiled for $1 \mathrm{~h}$ at $100^{\circ} \mathrm{C}$ in a water bath covering the tube with aluminium foil to prevent excess evaporation. Subsequently, it was cooled in an ice bath and $4 \mathrm{~mL}$ of toluene was added to each tube using a dispensor. Each tube was then shaken vigorously for 15 to $20 \mathrm{~s}$ in an electrical shaker and the layer was allowed to separate for $30 \mathrm{~min}$. The absorbance of the layer was measured using a spectrophotometer at $520 \mathrm{~nm}$ with pure toluene as a blank. Proline content was expressed on a fresh weight basis from the standard curve, using standard L-proline according to the previous method developed ${ }^{16}$.

\section{Yield and yield character}

Number of spikes, grain and straw dry weight per unit area: The samples were collected from an area of $1 \mathrm{~m} \times 1 \mathrm{~m}$ from the center of each plot by cutting the plant at ground level. Then ears were counted and collected in a cloth bag $(30 \mathrm{~cm} \times 45 \mathrm{~cm})$. The samples were dried in sun, threshed and cleaned manually and fresh weight of grain was taken. The husk, straw and representative samples of grain were dried in an oven at $70^{\circ} \mathrm{C}$ to constant weight to obtain grain and straw dry weight. Total dry weight $/ \mathrm{m}^{2}$ was calculated by adding grain, husk and straw dry weight.

Number of kernels per spike: Ten spikes were collected randomly per plot and number of kernels per spike was counted manually.

Individual kernel size: From each plot thousand grains were taken randomly from dried sample and weighed. From this weight, average individual kernel size was calculated.

Biological yield, straw yield and grain yield: The biological yield, straw yield and grain yield were expressed in $\mathrm{t} / \mathrm{ha}$, grain yield also adjusted to $12 \%$ moisture.

Heat susceptibility index: Heat susceptibility index (S) was calculated for grain yield using the following formula ${ }^{17}$.

$$
\mathrm{S}=\left(1-\mathrm{Y} / \mathrm{Y}_{\mathrm{p}}\right) /\left(1-\mathrm{X} / \mathrm{X}_{\mathrm{p}}\right)
$$

Where,

$$
\begin{aligned}
& Y=\text { Grain yield of genotype in a stress } \\
& \text { environment } \\
& Y_{p}=\text { Grain yield of genotype in a stress-free } \\
& \mathrm{X}=\text { Mean } \mathrm{Y} \text { of all cultivars } \\
& \mathrm{X}_{\mathrm{p}}=\text { Mean } \mathrm{Y}_{\mathrm{p}} \text { of all cultivars }
\end{aligned}
$$

( $\mathrm{S}: 0.5$, Highly stress tolerant; $0.5 \leq \mathrm{S} \leq 1.0$, moderately stress tolerant and $S 1.0$, stress susceptible)

Relative performance: The relative performance was calculated by the following formula ${ }^{18}$.

Variablc measured under stress condition

Relative performance $(\%)=$ $\mathrm{X} 100$

Variable measured under normal condition

Statistical analysis: All the collected and calculated data were analyzed statistically following the ANOVA technique and means were adjudged by Duncan's Multiple Range Test (DMRT) at 5\% level of significance according to previous studies $^{19}$. In membrane thermostability test, only mean values were used and SE (Standard Error for replication) values were calculated. Correlation and regression analysis were also done according to previous studies ${ }^{19}$.

\section{RESULTS AND DISCUSSION}

All wheat cultivars sown in the field on November 30 were exposed to $<26^{\circ} \mathrm{C}$ during the reproductive growth phase which was very close to the normal temperature of $22-26^{\circ} \mathrm{C}$ required for reproductive growth ${ }^{4,20}$ and $\geq$ considered as normal growing condition. On the other hand, when sown on December 30, they experienced high temperature $\left(>26^{\circ} \mathrm{C}\right)$ during the reproductive phase and was regarded as post anthesis heat stress (Figure 1).

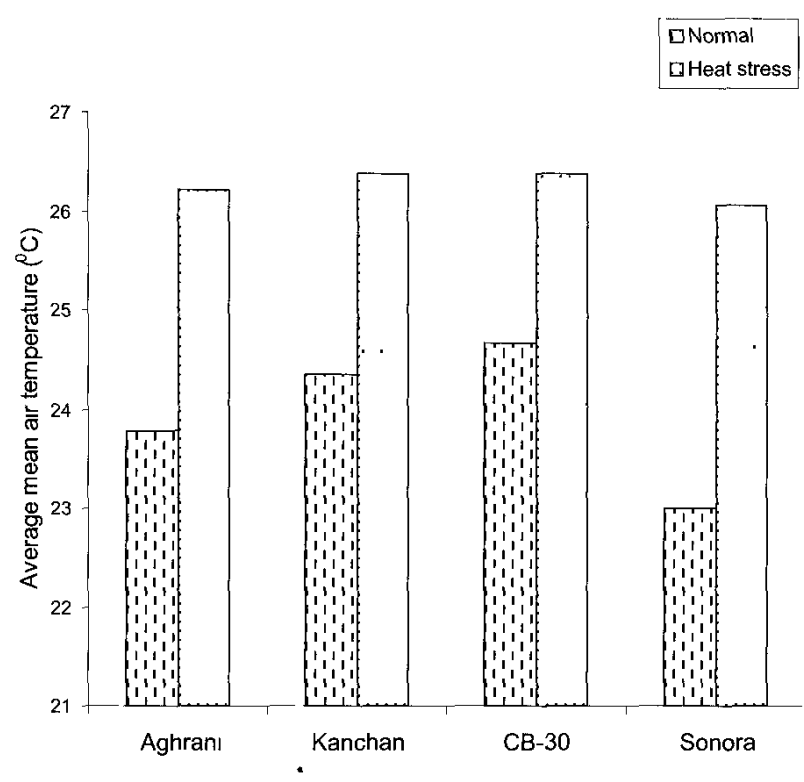

Figure 1: Average mean air temperature $\left({ }^{10} \mathrm{C}\right)$ received by different wheat cultivars

Source: Plant Physiology Division, BRRI, Gazıpur, Bangladesh 
Table 1: Relatrve heat tolerance of wheat cultrvars as determued by per cent membrane leakage (mean \pm SE) of flag leaf tisuue and tume to attam that injury

\begin{tabular}{|c|c|c|c|c|c|c|c|c|c|c|}
\hline \multirow{2}{*}{$\frac{2}{3}$} & \multirow{2}{*}{ 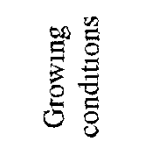 } & \multicolumn{9}{|c|}{ Membrane leakage $(\%)$ at $55^{\circ} \mathrm{C}$ temperature } \\
\hline & & $\begin{array}{c}30 \\
\text { min }\end{array}$ & $\begin{array}{r}60 \\
\text { mun }\end{array}$ & $\begin{array}{c}90 \\
\mathrm{~min}\end{array}$ & $\begin{array}{l}120 \\
\min \end{array}$ & $\begin{array}{l}150 \\
\text { min }\end{array}$ & $\begin{array}{l}180 \\
\text { min }\end{array}$ & $\begin{array}{l}210 \\
\mathrm{~mm}\end{array}$ & $\begin{array}{l}240 \\
\mathrm{~mm}\end{array}$ & $\begin{array}{l}270 \\
\text { min }\end{array}$ \\
\hline \multirow{3}{*}{ Aghram } & Normal & $\begin{array}{l}2879 \\
\pm 085\end{array}$ & $\begin{array}{l}3873 \\
\pm 065\end{array}$ & $\begin{array}{l}4312 \\
\pm 053\end{array}$ & $\begin{array}{l}4850 \\
\pm 053\end{array}$ & $\begin{array}{l}50.85 \\
\pm 0.33\end{array}$ & $\begin{array}{l}5301 \\
\pm 016\end{array}$ & $\begin{array}{l}5687 \\
\pm 109\end{array}$ & $\begin{array}{l}6854 \\
\pm 114\end{array}$ & $\begin{array}{l}7483 \\
\pm 063\end{array}$ \\
\hline & Heat stress & $\begin{array}{l}2807 \\
\pm 075\end{array}$ & $\begin{array}{l}3669 \\
\pm 022\end{array}$ & $\begin{array}{l}4233 \\
\pm 062\end{array}$ & $\begin{array}{l}4826 \\
\pm 039\end{array}$ & $\begin{array}{l}50.22 \\
\pm 0.20\end{array}$ & $\begin{array}{l}5154 \\
\pm 047\end{array}$ & $\begin{array}{l}5565 \\
\pm 100\end{array}$ & $\begin{array}{l}6797 \\
\pm 076\end{array}$ & $\begin{array}{l}7388 \\
\pm 082\end{array}$ \\
\hline & Normal & $\begin{array}{l}3737 \\
\pm 042\end{array}$ & $\begin{array}{l}4145 \\
\pm 046\end{array}$ & $\begin{array}{l}4835 \\
\pm 042\end{array}$ & $\begin{array}{l}51.24 \\
\pm 0.25\end{array}$ & $\begin{array}{l}5668 \\
\pm 043\end{array}$ & $\begin{array}{l}6237 \\
\pm 059\end{array}$ & $\begin{array}{l}7282 \\
\pm 018\end{array}$ & $\begin{array}{l}7721 \\
\pm 093\end{array}$ & $\begin{array}{l}8123 \\
\pm 063\end{array}$ \\
\hline \multirow[t]{2}{*}{ Kanchan } & Heat stress & $\begin{array}{l}3555 \\
\pm 058\end{array}$ & $\begin{array}{l}4018 \\
\pm 033\end{array}$ & $\begin{array}{l}4604 \\
\pm 065\end{array}$ & $\begin{array}{l}\mathbf{5 0 . 2 9} \\
\mathbf{\pm 0 . 2 7}\end{array}$ & $\begin{array}{l}5696 \\
\pm 065\end{array}$ & $\begin{array}{l}6087 \\
\pm 108\end{array}$ & $\begin{array}{l}7157 \\
\pm 055\end{array}$ & $\begin{array}{l}7641 \\
\pm 093\end{array}$ & $\begin{array}{l}8044 \\
\pm 102\end{array}$ \\
\hline & Normal & $\begin{array}{l}3615 \\
\pm 057\end{array}$ & $\begin{array}{l}4457 \\
\pm 039\end{array}$ & $\begin{array}{l}4807 \\
\pm 049\end{array}$ & $\begin{array}{l}\mathbf{5 0 . 4 1} \\
\mathbf{\pm 0 . 4 2}\end{array}$ & $\begin{array}{l}5604 \\
\pm 083\end{array}$ & $\begin{array}{l}6423 \\
\pm 099\end{array}$ & $\begin{array}{l}7264 \\
\pm 073\end{array}$ & $\begin{array}{l}7815 \\
\pm 103\end{array}$ & $\begin{array}{l}8314 \\
\pm 058\end{array}$ \\
\hline \multirow[t]{2}{*}{ CB 30} & Heat stress & $\begin{array}{l}3315 \\
\pm 053\end{array}$ & $\begin{array}{l}4315 \\
\pm 069\end{array}$ & $\begin{array}{l}4682 \\
\pm 042\end{array}$ & $\begin{array}{r}49.89 \\
\pm 0.22\end{array}$ & $\begin{array}{l}5554 \\
\pm 085\end{array}$ & $\begin{array}{l}6373 \\
\pm 076\end{array}$ & $\begin{array}{l}7139 \\
\pm 052\end{array}$ & $\begin{array}{l}7740 \\
\pm 057\end{array}$ & $\begin{array}{l}8164 \\
\pm 071\end{array}$ \\
\hline & Normal & $\begin{array}{l}51.49 \\
\pm 1.14\end{array}$ & $\begin{array}{l}5703 \\
\pm 075\end{array}$ & $\begin{array}{l}6210 \\
\pm 085\end{array}$ & $\begin{array}{l}6973 \\
\pm 084\end{array}$ & $\begin{array}{l}7522 \\
\pm 025\end{array}$ & $\begin{array}{l}7813 \\
\pm 069\end{array}$ & $\begin{array}{l}8086 \\
\pm 060\end{array}$ & $\begin{array}{l}8471 \\
\pm 054\end{array}$ & $\begin{array}{l}8692 \\
\pm 032\end{array}$ \\
\hline Sonora & Heat stress & $\begin{array}{l}\mathbf{5 1 . 5 0} \\
\pm 0.76\end{array}$ & $\begin{array}{l}5753 \\
\pm 044\end{array}$ & $\begin{array}{l}6226 \\
\pm 066\end{array}$ & $\begin{array}{l}7005 \\
\pm 075\end{array}$ & $\begin{array}{l}7582 \\
\pm 060\end{array}$ & $\begin{array}{l}7863 \\
\pm 060\end{array}$ & $\begin{array}{l}8142 \\
\pm 070\end{array}$ & $\begin{array}{l}8513 \\
\pm 042\end{array}$ & $\begin{array}{l}8641 \\
\pm 025\end{array}$ \\
\hline
\end{tabular}

Table 2: Flag leaf and kernel proline content in wheat genotypes at 8 days after anthesis under normal conditıon and post anthesis heat stress condition

\begin{tabular}{ccccccc}
\hline Cultivars & \multicolumn{3}{c}{$\begin{array}{c}\text { Flag leaf proline content } \\
(\mu \text { mole/g fresh wt })\end{array}$} & \multicolumn{3}{c}{$\begin{array}{c}\text { Kernel proline content } \\
(\mu \text { mole/g fresh wt })\end{array}$} \\
\hline & $\begin{array}{c}\text { Normal } \\
\text { condition }\end{array}$ & $\begin{array}{c}\text { Heat stress } \\
\text { condition }\end{array}$ & $\begin{array}{c}\text { condition } \\
\text { change to } \\
\text { normal }(\%)\end{array}$ & condition & condition & $\begin{array}{c}\text { Relative } \\
\text { change to } \\
\text { normal }(\%)\end{array}$ \\
\hline Aghranı & $069 \mathrm{e}$ & $079 \mathrm{~d}$ & +1449 & $159 \mathrm{~d}$ & $125 \mathrm{e}$ & 2138 \\
Kanchan & $096 \mathrm{c}$ & $125 \mathrm{a}$ & +3020 & $195 \mathrm{c}$ & $120 \mathrm{e}$ & -3846 \\
CB-30 & $087 \mathrm{~d}$ & $128 \mathrm{a}$ & +4713 & $247 \mathrm{~b}$ & $187 \mathrm{c}$ & -243 \\
Sonora & $050 \mathrm{f}$ & $111 \mathrm{~b}$ & +12200 & $358 \mathrm{a}$ & $189 \mathrm{c}$ & -4721 \\
CV $(\%)^{*}$ & 538 & - & 377 & - & &
\end{tabular}

Means followed by the same letter (s) did not differ significantly at $5 \%$ level by DMRT

* means Coefficient of Varıation (\%) which undicates the reliability of an experıment

\section{Cell membrane thermostability (CMT):}

$\mathrm{CMT}$ as determined by relative electrolyte leakage at $55^{\circ} \mathrm{C}$ elevated temperature differed among the wheat cultivars under both normal and post anthesis heat stress conditions (Table 1). Time required to reach $50 \%$ membrane leakage in a cultivar was considered to be its heat killing time. The longest heat killing time (150 minutes.) was observed in Aghrani and it was closely followed by
Kanchan (120 minutes) and CB-30 (120 minutes) both under normal and post anthesis heat stress conditions. Among the cultivars Sonora showed the shortest heat killing time ( 30 minutes) irrespective of growing conditions. Therefore, under post anthesis heat stress condition, the cultivars Aghrani, Kanchan and CB-30 showed somewhat lower membrane leakage at any particular time after exposure to elevated temperature compared to the normal condition. This could be due to 
the tendency of the genotypes to acclimatize against high temperature stress.

In Sonora almost similar membrane leakage both under normal and heat stressed conditions at a particular time indicated the absence of acclimation ability of this genotype. Based on the heat killing time, Aghrani, Kanchan and CB-30 are considered as heat tolerant (HT) cultivars while Sonora is considered as a heat sensitive (HS) cultivar.

Under heat stress, the activity of superoxide dimutase and catalase increased more in heat tolerant wheat genotypes than in the sensitive one ${ }^{21}$. As the high temperature membrane injury was caused by free radicals, the higher activity of superoxide di-mutase and catalase may be important in the higher membrane thermostability in tolerant cultivars. Genotypic differences in membrane thermostability have also been reported in wheat by different scientists ${ }^{22-29}$.

\section{Proline content}

Proline content in flag leaves and kernels of different wheat cultivars at 8 days after anthesis was significantly influenced by post anthesis heat stress conditons (Table 2). Proline content in the flag leaves was significantly higher in heat tolerant cultivars i.g. in Aghrani (0.69 $\mu$ mole/ g. fresh wt.), Kanchan $(0.96 \mu \mathrm{mole} / \mathrm{g}$. fresh wt. $)$ and CB-30 $(0.87 \mu \mathrm{mole} /$ g. fresh wt.) than that in heat sensitive Sonora $(0.50 \mu \mathrm{mole} / \mathrm{g}$. fresh wt.) under normal growing condition. Relative changes due to heat stress indicated that there was significant increase in flag leaf proline of wheat compared to normal condition. However, the percent increment was lower (14.49\% to $47.13 \%$ ) in heat tolerant cultivars than in heat sensitive cultivars $(122 \%)$. Again, under normal growing condition, the kernel proline content at 8 days after anthesis was recorded to be significantly lower (1.59 to $2.47 \mu \mathrm{mole} / \mathrm{g}$ ) in heat tolerant cultivars (Aghrani, Kanchan and CB-30) than in heat sensitive Sonora $(3.58 \mu \mathrm{mole} / \mathrm{g})$. Kernel proline content was significantly lower under post anthesis heat stress condition than under normal condition in all cultivars but the per cent reduction of kernel proline content was lower $(24.3 \%$ to $38.46 \%$ ) in heat tolerant cultivars than in heat sensitive Sonora (47.21\%). Relative to normal growing condition the sharp increase in flag leaf proline along with larger decrease in kernel proline under heat stress condition clearly indicate the sensitivity of the genotype (Sonora) to post anthesis heat stress. In other words, smaller changes in proline level due to heat stress were observed in heat tolerant cultivars. These results are found in various crops ${ }^{13}$, in Mulberry leaves, in Groundnut ${ }^{14,30}$, in Brassica ${ }^{12}$ and in Cucumber ${ }^{31}$.

Number of spikes per unit area

Number of spikes per unit area was not influenced significantly by the interaction effect of growing

Table 3: Yield, yield characters and heat susceptibility index of different wheat cultivars under normal and post anthesis heat stress conditions

\begin{tabular}{|c|c|c|c|c|c|c|c|c|}
\hline & & $\begin{array}{l}\text { No. of } \\
\text { spikes } \\
\text { per } \mathrm{m}^{2}\end{array}$ & $\begin{array}{c}\text { No. of } \\
\text { kernels } \\
\text { per } \\
\text { spike }\end{array}$ & $\begin{array}{c}\text { Individual } \\
\text { kernel } \\
\text { weight }\end{array}$ & $\begin{array}{l}\text { Grain } \\
\text { yield } \\
(\mathrm{t} / \mathrm{ha})\end{array}$ & $\begin{array}{l}\text { Straw } \\
\text { yield } \\
(\mathrm{t} / \mathrm{ha})\end{array}$ & $\begin{array}{c}\text { Biological } \\
\text { yield } \\
\text { (t/ha) }\end{array}$ & $\begin{array}{l}{ }^{\star} \mathrm{HSI} \\
\text { for } \\
\text { grain } \\
\text { yield }\end{array}$ \\
\hline Aghrani & Normal & $225 \mathrm{~b}$ & $60.3 \mathrm{a}$ & $41.4 \mathrm{a}$ & $4.94 \mathrm{a}$ & $4.71 \mathrm{a}$ & $9.06 \mathrm{a}$ & 0.962 \\
\hline Heat stress & $222 b$ & $58.3 \mathrm{a}$ & $34.3 \mathrm{~d}$ & $4.34 \mathrm{bc}$ & $3.82 \mathrm{c}$ & $7.64 \mathrm{c}$ & & \\
\hline Kanchan & Normal & 277 a & $49.3 \mathrm{de}$ & $41.2 \mathrm{a}$ & $4.32 \mathrm{bc}$ & $4.81 \mathrm{a}$ & $8.61 \mathrm{~b}$ & 0.902 \\
\hline Heat stress & 273 a & $47.2 \mathrm{e}$ & $34.8 \mathrm{~d}$ & $3.82 \mathrm{de}$ & $4.32 \mathrm{~b}$ & $7.67 \mathrm{c}$ & & \\
\hline $\mathrm{CB}-30$ & Normal & $229 \mathrm{~b}$ & $59.5 \mathrm{a}$ & $38.0 \mathrm{c}$ & $4.07 \mathrm{~cd}$ & $4.38 \mathrm{~b}$ & $7.96 c$ & 0.346 \\
\hline Heat stress & $228 \mathrm{~b}$ & $54.5 \mathrm{~b}$ & $34.9 \mathrm{~d}$ & $3.89 \mathrm{de}$ & $3.95 \mathrm{c}$ & $7.34 \mathrm{~d}$ & & \\
\hline Sonora & Normal & 261 a & $52.3 \mathrm{bc}$ & $39.4 \mathrm{~b}$ & $4.53 \mathrm{~b}$ & $4.66 \mathrm{a}$ & $8.63 \mathrm{~b}$ & 1.721 \\
\hline Heat stress & $260 \mathrm{a}$ & $47.5 \mathrm{e}$ & $30.5 \mathrm{e}$ & $3.54 \mathrm{e}$ & $3.72 \mathrm{c}$ & $6.97 \mathrm{~d}$ & & \\
\hline $\mathrm{CV}(\%)^{*}$ & 3.53 & 3.15 & 1.23 & 5.98 & 5.54 & 5.21 & - & \\
\hline
\end{tabular}

Means followed by the same letter (s) did not differ significantly at 5\% level by DMRT

* HSI indicates Heat Susceptibility Index

* means Coefficient of Variation (\%) which indicates the reliability of an experiment. The lower the CV\% value indicates the higher the reliability 
conditions and cultivars but it differed significantly among cultivars (Table 3). Kanchan had the highest number of spikes per $\mathrm{m}^{2}(273$ to 277$)$ which were statistically similar to that of Sonora (260 to 261). Aghrani had the lowest number of spikes per $\mathrm{m}^{2}$ (222 to 225$)$ which were on par with CB-30 (228 to 229).

The insignificant interaction between growing conditions and wheat cultivars indicated that the differences in the number of spikes per $\mathrm{m}^{2}$ land area among the cultivars were mainly controlled genetically. Wheat plants did not suffer from heat stress in $\mathrm{GS}_{1}$ phase (emergence to double ridge) in which tillering was determined.

Results from other studies showed that the spike number per unit land area $\left(\mathrm{m}^{2}\right)$ was not influenced by the late sowing condition $^{28}$. He and Rajaram ${ }^{6}$ reported that the ear number per unit area was less sensitive while yield, grains per ear, biomass and plant height were more heat sensitive.

\section{Kernels per spike}

Kernel number per spike was influenced significantly by the interaction effect of growing conditions and cultivars (Table 3). Under normal growing condition, Aghrani had the highest number of kernels per spike (60.3) which was statistically similar to that of CB-30 (59.5). Kanchan had the lowest kernels per spike (49.3). Whereas, in case of Sonora, it was the second lowest (52.3). On the other hand, under post anthesis heat stress condition, this number reduced in all cultivars though the reduction was significant only for CB-30 and Sonora. The HS cultivar Sonora was affected more $(9.3 \%)$ with respect to reduction in kernels per spike than the HT genotypes Aghrani (3.3\%), Kanchan ( $4.3 \%)$ and CB-30 (8.5\%). Reduced number of kernels per spike of different magnitudes were also observed by other scientists ${ }^{4,7}$ under late sowing or high temperature condition compared to optimum sowing temperature.

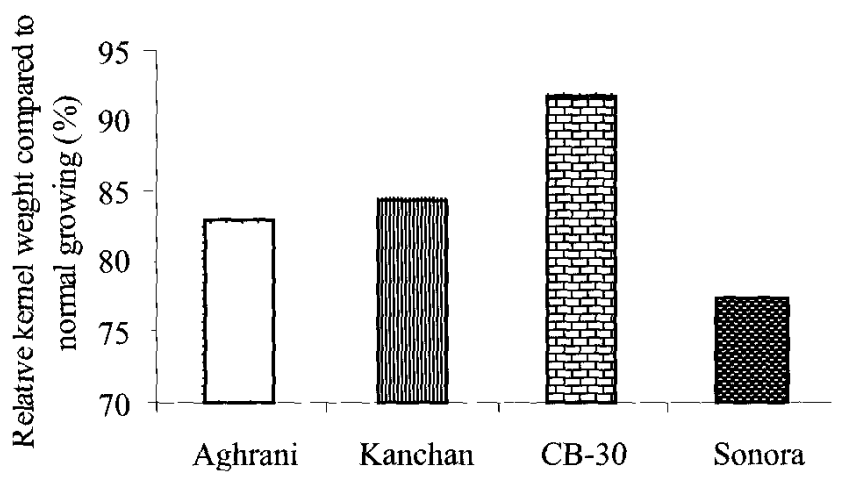

Figure 2: Relative kernel weight compared to normal growing condition in different wheat genotypes

\section{Kernel weight}

Individual kernel weight differed significantly due to the combined effect of growing conditions and wheat genotypes (Table 3). Under normal growing condition, maximum kernel weight was recorded in Aghrani $(41.4 \mathrm{mg} /$ kernel) which was statistically equal to that of Kanchan (41.2 mg/kernel). CB-30 showed the lowest kernel weight $(38.0 \mathrm{mg} / \mathrm{kernel})$ which followed the kernel weight of Sonora ( $39.4 \mathrm{mg} / \mathrm{kernel})$. These differences in kernel weight among the wheat genotypes could have been due to their genetic variation. Under post anthesis heat stress condition, kernel weight reduced significantly in all wheat cultivars. However, the magnitude of reduction was different in different genotypes. Under this condition, the HS genotype (Sonora) attained lower relative kernel weight compared to normal (77.4\%) than the HT cultivars Aghrani (82.9\%), Kanchan (84.5\%) and CB-30 (91.8\%) shown in Figure 2. Reduced kernel weight under heat stress condition might be due to the reduction in rapid kernel growth duration.

\section{Grain yield}

Growing conditions and wheat cultivars interacted significantly to govern the grain yield (Table 3). Under normal growing condition, Aghrani attained the highest grain yield ( $4.94 \mathrm{t} / \mathrm{ha}$ ) which was followed by Sonora ( 4.53 t/ha) and Kanchan (4.32 t/ha) whereas CB-30 gave the lowest grain yield $(4.07 \mathrm{t} / \mathrm{ha})$. Post anthesis heat stress condition decreased the grain yield significantly in all wheat genotypes but the amount of reduction was not equal in different cultivars. Percent relative yield to normal (78.2\%) was lower in heat sensitive Sonora whereas higher in the heat tolerant Aghrani (87.8\%), Kanchan (88.4\%) and CB-30 (95.6\%) shown in Figure 3.

Reduced number of kernels per spike and reduced kemel weight were the major factors responsible for reducing the

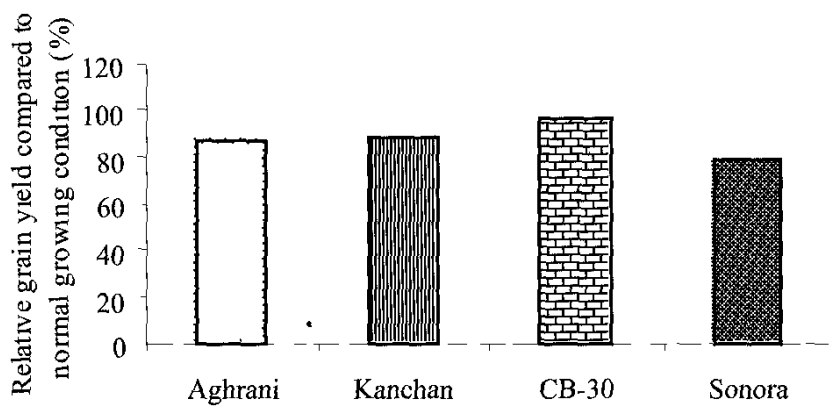

Figure 3: Relative grain yield compared to normal growing condition in different wheat genotypes 
Table 4: Correlation and regression of heat knlling tume in CMT test, heat susceptibility index for gram yield and relative change to normal in proline content

\begin{tabular}{|c|c|c|c|c|}
\hline \multicolumn{2}{|c|}{ Characters } & \multirow[t]{2}{*}{ Regresion equation } & \multirow{2}{*}{$\begin{array}{l}\text { Coefficient of } \\
\text { detcrmination } \\
\qquad\left(\mathrm{R}^{2}\right)\end{array}$} & \multirow{2}{*}{$\begin{array}{c}\text { Correlation } \\
\text { coefficient } \\
\text { (r) }\end{array}$} \\
\hline $\mathrm{X}$ & $\mathrm{Y}$ & & & \\
\hline Heat killing ttme in CMT test & $\begin{array}{l}\text { Relative change to normal in } \\
\text { flag leaf proline content }\end{array}$ & $Y=-096 X+148.58$ & 0.978 & $-0.989^{*}$ \\
\hline Heat kıllıng time in CMT test & $\begin{array}{l}\text { Relative change to normal in } \\
\text { kernel proline content }\end{array}$ & $Y=-020 X+54.06$ & 0.748 & $-0.865^{\star}$ \\
\hline $\begin{array}{l}\text { Heat susceptibility index for } \\
\text { grain yield }\end{array}$ & $\begin{array}{l}\text { Relative change to normal in } \\
\text { flag leaf proline content }\end{array}$ & $Y=59.87 X-5.38$ & 0.505 & $0.711^{\mathrm{ns}}$ \\
\hline $\begin{array}{l}\text { Heat susceptibility index for } \\
\text { grain yield }\end{array}$ & $\begin{array}{l}\text { Relative change to normal in } \\
\text { kernel proline content }\end{array}$ & $Y=1654 X+16.59$ & 0.591 & $0.769^{\mathrm{ns}}$ \\
\hline
\end{tabular}

grain yield under heat stress condition in the present experiment. Other yield attributes i.e., spike number per unit land area was not affected at high temperature (Table 3). Results from other studies have shown that late sowing caused lower grain yield in wheat compared to optimum sowing ${ }^{5,7}$. Scientists ${ }^{4}$ concluded that high relative grain yield which was the result of stable and/or long duration of photosynthetic activity under heat stress condition could be considered as a selection criterion for heat tolerance of wheat cultivars.

\section{Straw yield}

The straw yield was significantly influenced by the interaction effect of growing condition and cultivars (Table 3). Maximum straw yield was recorded from Kanchan (4.81 t/ha) which was statistically similar to that of Aghrani (4.71 t/ha) and Sonora (4.66 t/ha) but significantly lower than in CB-30 (4.38 t/ha). Genetic variation was the responsible factor for this variation under normal growing condition. On the other hand, under heat stress condition straw yield was reduced significantly in all wheat genotypes. However, the degree of reduction varied in different wheat cultivars. Here the relative value of straw yield to control was lower in HS cultivar (79.8\%) than that in the heat tolerant Aghrani (81.7\%), Kanchan (89.8\%) and CB-30 (90.2\%).

The different magnitudes of reduction in straw yield among the wheat cultivars might be due to the different degrees of reduction in pre-anthesis growth duration under high temperature stress. There are reports ${ }^{24}$ that the HT cultivars attained less reduction in pre-anthesis growth duration compared to that in HS cultivars under late growing condition. Scientists ${ }^{20}$ also reported less vegetative biomass production under high temperature. These results support the above findings. On the other hand, under heat stress condition straw yield was reduced significantly in all wheat cultivars. But the degree of reduction varied in different wheat cultivars.

\section{Total biomass}

Total biomass of wheat was significantly influenced by the interaction effect of growing conditions and cultivars (Table 3). Under normal growing condition, Aghrani gave significantly higher total biomass $(9.06 \mathrm{t} / \mathrm{ha})$ than that of Sonora (8.63 t/ha) and Kanchan $(8.61 \mathrm{t} / \mathrm{ha})$, though the difference in total biomass between Sonora and Kanchan was not significant. CB-30 gave significantly the lowest yield $(7.96 \mathrm{t} / \mathrm{ha})$.

Under post anthesis heat stress condition, total biomass decreased significantly in all wheat cultivars but the degree of reduction was not similar in all cultivars. The

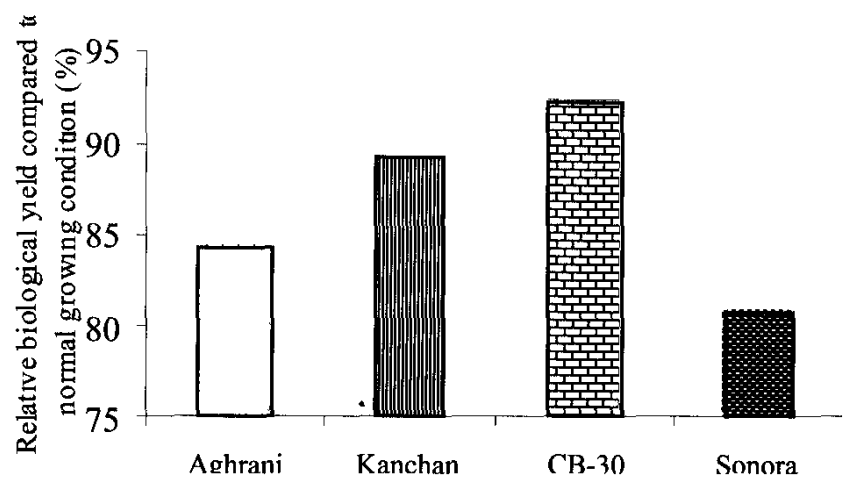

Figure 4: Relative biological yield compared to normal growing condition in different wheat genotypes 
HT cultivars, Aghrani, Kanchan and CB-30 showed greater per cent relative total biomass to normal ( 84.3 to $92.2 \%$ ) than the HS cultivar Sonora (80.8\%) shown in Figure 4. The reduced total biomass in wheat under heat stress was due to the reduced grain and straw yield. Scientists ${ }^{5}$ also reported reduced total biomass under high temperature.

\section{Heat susceptibility index}

Heat susceptibility index based on grain yield varied in different wheat cultivars (Table 3 ). According to the susceptibility index, CB-30 (0.346) was found to be heat tolerant, Aghrani (0.962) and Kanchan (0.90) were moderately tolerant and Sonora (1.721) was found to be a heat susceptible cultivar.

\section{Correlation and regression analysis}

Table 4 shows that strong negative correlation exists between heat killing time in CMT test and relative change to normal in proline content (both in flag leaf and kernel). The correlations were also significant at $5 \%$ level of probability. The correlation between heat susceptibility index for grain yield and relative change to normal in proline content (both in flag leaf and kernel) were strong though positive and insignificant at $5 \%$ level of probability.

\section{CONCLUSION}

From the overall results it may be concluded that proline content can be used as a selection criterion for screening heat tolerant wheat cultivars. But more investigations with a larger number of cultivars are nesessary for confirmation.

\section{References}

1. FAO (1999). An appraisal of seed biology and the yield of grain crops. Production Year Book. pp. 234-235. Food and Agriculture Organization, Rome.

2. Anon. (2000).Gom Utpadon Projukti (in Bengali). pp. 3-4. Wheat Research Centre, Bangladesh Agricultural Research Institute, Nashipur, Dinajpur, Bangladesh.

3. Badruddin M., Saunders D.A., Siddique A.B., Hossain M.A., Ahmed M.O., Rahman M.M. \& Parveen S. (1994). Determining yield constraints for wheat production in Bangaldesh. In: Wheat in Heat Stressed Environments; Irrigated, Dry Areas and Rice-Wheat Farming systems (Eds. D. A. Saunders \& G. P. Hettel) pp. 265-271. CIMMYT, Mexico.

4. Al-Khatib K. \& Paulsen G.M. (1990). Photosynthesis and productivity during high temperature stress of wheat genotypes from major world regions. Crop Science 30: 1127 1132.

5. Bhatta M.R., Hernandez J.E. \& Lates J.S. (1994). Possibilities of selecting wheats with fast grain filling rate for warmer areas. In: Wheat in Heat-stressed Environments: Irrigated,
Dry Areas and Rice-Wheat Farming Systems (Eds. D. A. Saunders \& G. P. Hettel) pp. 375-378. CIMMYT, Mexico.

6. He Z.H. \& Rajaram S. (1993). Differential responses of bread wheat characters to high temperature. Euphytica 72: 197-203.

7. Islam N., Ahmed S.M., Razzaque M.A., Sufian A. \& Hossain M.A. (1993). A study on the effect of seeding dates on the yield of wheat varieties. Bangladesh Journal of Agricultural Research 18(1):102-107.

8. Acevedo E., Nachit M. \& Ferrana G.O. (1991). Effects of heat stress on wheat and possible selection tools for use in breeding for tolerance. In: Wheat for the non-traditional warm areas. (Ed. D.A. Saunders) pp. 401-420. CIMMYT, Mexico.

9. Asana R.D. \& Saini A.D. (1962). Studies in physiological analysis of yield V. Grain development in wheat relation to temperature, soil moisture and changes with age in the sugar content of the stem and in the photosynthetic surface. Indian Journal of Plant Physiology 5: 128-71.

10. Karmakar S. \& Shrestha M.L. (2000). Recent climatic changes in Bangladesh. No. 4. pp. 37-38. SAARC Meteorological Research Centre, Agargaon, Dhaka.

11. Chaitanya K.V., Sundar D. \& Reddy A.R. (2001). Mulberry leaf metabolism under high temperature stress. Biologia Plantarum 44(3): 379-384.

12. Hossain M.M., Takeda H. \& Senboku T. (1995). Proline content in Brassica under high temperature stress. JIRCAS (Japan International Research Centre for Agricultural Science) Journal 2: 87-93.

13. Maiti R.K., Moreno L.S. \& Wesche E.P. (2000). Responses of some crops to various abiotic stress factors and its physiological and biochemical basis of resistance: a review. Agricultural Reviews. 21(3):155-167. Puebla-72820, Mexico.

14. Takeda H., Cenpukelee U., Chauhan Y.S., Srinivasan A., Hossain M.M., Rashad M.H., Lin B., Tolwar H.S., Senboku T., Varhima S., Yanagihara S., Shono M., Ancho S., Lin B.Q., Yajima M. \& Hayashi T. (1999). Studies in heat tolerance of Brassica vegetables and legumes at the International Colloboration Research station from 1992 to 1996. Proceedings of a workshop on heat tolerance of crops. Okinawa. Japan, 7-9 October 1997. JIRCAS (Japan International Research Centre for Agricultural Science) working Report 14: 17-29.

15. Kou C.G., Chen H.M. \& Ma L.H. (1986). Effect of high temperature on proline content in tomato floral buds and leaves. Journal of the American Society for Horticultural Science 11: 734-750.

16. Troll W. \& Lindsley J. (1955). A photometric method for the determination of proline. Journal of Biological Chemistry 215: 655-660.

17. Fisher R.A. \& Maurer R. (1978). Drought resistance in spring wheat cultivars. I. Grain yield responses. Australian Journal of Agricultural Research 29: 897-907.

18. Asana R.D. \& Williams R.F. (1965). The effect of temperature stress on grain development in wheat. Australian Journal of Agricultural Research 16: 1-3.

19. Gomez K.A. \& Gomez A.A. (1984). Statistical Procedures for Agricultural Research. pp. 397-411. John Willey and Sons, New York. 
20. Campbell C.A. \& Read D.W.L. (1968). Influence of air temperature, light intensity and soil moisture on the growth, yield and some growth analysis charateristics of chioiolo wheat grown in the growth chamber. Canadian Journal of Plant Science 48: 299-311.

21. Zhou R.G., Fan Z.H., Li X.Z., Wang Z.W. \&. Han W. (1995). The effect of heat acclimation on membrane thermostability and relative enzyme activity. Acta Agronomica Sinica 21(5): 568-572.

22. Blum A., Klueva N. \& Nguyen H.T. (2001). Wheat cellular thermotolerance is related to yield under heat stress. Euphytica 117(2): 117-123.

23. Fokar M., Nguyen H.T. \& Blum A. (1988). Heat tolerance in spring wheat I. Estimating cellular thermotolerance and its heritability. Euphytica 104(1): 1-8.

24. Haque M.Z. (2002). Heat tolerant characteristics in wheat under late seeded condition. MS Thesis, pp. 49-59. Department of Crop Botany, BSMRAU, Sanla, Gazipur, Bangladesh.

25. Hossain M.M., Takeda H. \& Senboku T. (1995). Improved method of determination of membrane thermostability for screening heat-tolerant and sensitive varieties of Brassica. JIRCAS (Japan International Research Centre for Agricultural Science) Journal 2(1): 19-27.
26. Saadalla M.M., Quick J.S.\& Shanahan J.F. (1990). Heat tolerance in winter wheat II. Membrane thermostability and field performance. Crop Science 30: 1248-1251.

27. Shanałan J.F., Edwards I.B. Quick J.B. \& Fenwick J.R. (1990). Membrane and heat tolerance of spring wheat. Crop Science 30: 247-251.

28. Sharma R.T. \& Tandon J.P. (1998). Cell membrane thermostability $\mathrm{I}$. A measurement of heat tolerance in wheat. Agricultural Science Digest 18(3): 178-180.

29. Sikder S., Ahmed J.U., Hossain T., Miah M.A.K. \& Hossain M.M. (1999). Membrane thermostability, grain growth and contribution of pre-anthesis stem reserve to grain weight under late seeded condition. Thai Journal of Agricultural Science 32(4): 465-473.

30. Talwar H.S., Yanagihara S., Yajima M.\& Hayashi T. (1999). Physiological basis of heat tolerance during flowering and pod setting stages in groundnut (Arachis hypogaea L.) Proceedings of a workshop on heat tolerance of crops, Okinawa, Japan, October 1997 JIRCAS (Japan International Research Centre for Agricultural Science) working Report 14: 47-65.

31. Zhang M., Cui H.W. \& Zhao S. (1998). Free proline contents and catalase activity in cucumber leaves at elevated temperatures. Cucurbit Genetics Cooperative Report 31: 16-17. 